\title{
The impact of Foreign Direct Investment on Economic Growth in Niger
}

\author{
Ms.Mounkaila Noma Kadiatou ${ }^{1}$ \\ ${ }^{I}$ (School of Finance, Zhongnan University of Economics and Law, PRC)
}

\begin{abstract}
The main target of this paper is to analyze the impact of foreign direct investment on Niger economic growth by employing time series dates over the period 1980-2005. The data of this study come from different sources such as, World Development Indicators, the Niger Investment Agency, and the office of national statistics (INS). To determine the relationship among FDI and economic growth, we used Ordinary Least Square $(O L S)$ and granger causality test as econometric methodologies. The findings revealed that foreign direct investment has a positive and statistically significant contribution on Niger's economic growth. The granger causality test shows a bidirectionary causation running from FDI to GDP and vice -versa but no strong .This study recommends: that local government must continue to ensure Business Friendly Environment in the purpose to attract more investors and to maintain Political and economic Stability at all stages in Niger.

Keywords: Economic Growth, Foreign Direct Investment, granger causality, Niger, OLS.
\end{abstract}

\section{Introduction}

Many scholars are looking foreign direct investment (FDI) as a possible source of capital in the countries, FDI become like the road for growth in many countries in the world. As a possible source of growth, the role of FDI has become more and more important in developing countries. Many literature agree that there is a connection among foreign direct investment (FDI) and growth (Hansen and Rand, 2004); Klein et al. 2001). As a possible source of growth, FDI occupied an important place in developing countries.In the 1980s, developing countries as Africa needed to invest funds and start removing barriers to foreign investment, as well as providing tax breaks and other incentives (Afsar, 2004: 88.93, 96). Due to the implementation of policies to increase the liquidity of foreign capital between countries, the inflow of foreign capital has increased significantly (Afsar, 2004: 88). Although a significant increase in foreign direct investment (FDI), but the discussion about its impact on growth is still practical. FDI inflows not only provide, but also result in the transfer of technology and information to improve business productivity, and increase the positive impact on the economy as a whole. However, these arguments were questioned (Caves, 1971: 26-27).

Foreign direct investment (FDI) is a direct investment into production or business in a host country by an individual or firms of foreign countries, also by purchasing a company in the host country or by increasing activities of a present business in the host country. It is important to know that foreign direct investment is different from portfolio investment which is a passive investment in the securities of investor country such as stocks, bonds and any other financial security. The investors buy some non-controlling portion of all kind of securities.The World Bank (1996) is defined Foreign Direct Investment (FDI) as investment that is made to obtain the benefit of lasting management (generally $10 \%$ of voting shares) holding in an enterprise and operating in the host country (explain according to residency) the goal of investors is to have an effective voice in the profits management both long-term capital or short-term capital, as shown in the national balance of payments statements of account (Macaulay, 2012).In general, foreign direct investment, encloses Joint venture and acquisitions, construction of new facilities, re investment of earnings made by overseas activities, and intra firm loans. In a fine way, FDI refers only to making new facilities.Usually we seen FDI as a combination bundle of technology and capital stock, and can enhance the present stock of knowledge in the host country, According to (De Mello, 1999), economy finished the training of labour, the skill acquisition and diffusion, and making place of new managerial practices and organizational activities.In the same point (Todaro, 1977) think that foreign direct investment boost the inflows of technology and skilled workforces, and close the gap among national accessible supplies of savings, foreign exchange and government revenue. After the World War II, the contribution of FDI help seriously both Japan and South Korea to assist their economic growth providing the national economy with many support such as: foreign knowledge, management expertise, technology, and human resource development via international cooperation and training (Onu, 2012).

Niger is a landlocked country in West African country with open economy. Niger's economic growth over the past several decades has been relatively modest except for a brief period during the uranium boom years of 1975-1982 when economic activity intensified. When growth came to an abrupt end with the collapse of the world uranium market, the economy fell into period of recession, a slowdown in investment and a weakening of the financial sector. This situation has created savings and foreign exchange gap in Niger but it is 
knowing that foreign direct investment is an engine of economic growth, by assisting domestic investment, creates new jobs opportunities and is in most cases related to the enhancement of technology transfer and managerial specialization, which of course can boost Niger economic growth. The Niger governments have recognized the importance of FDI in enhancing economic growth and development and various strategies involving incentive policies and regulatory measure have been put in place to promote the inflow of FDI to the country so the FDI has been chosen as a strategy to boost the economic growth. The main objective of this article is to analyze the impact of Foreign Direct Investment on Niger economic Growth within the period 19802005. The paper is organized into sections as follows: Section one presented the introduction to the study next section two deals with a review of literature. Section three outlines data and methodology used in the paper. The empirical result is discussing in section 4 and finally the conclusion and recommendations in the last section.

\section{Review Of Literature}

Research on the relationship between FDI and economic growth is ongoing.( Denisa , 2010) said that FDI developed a crucial role in the international economy after the Second World War, so several researchers have piloted empirical studies to investigate the impact of FDI and economic growth. They have found a positive relationship and other negative others have found no as relationship depending on the reality of the host countries such as: economic, institutional and technological conditions. In this part previous literature are reviewed and the significant hypotheses are settled. These reviews offer a largely understanding of the study that is being investigated in this paper,

Theoretically, FDI is supposed to directly impact growth through capital accumulation, and the incorporation of new inputs and foreign technologies in the production function of the host country. HarrodDomar model is the theoretical basis for analyzing the impact of investment on economic growth. In the view of neoclassical or exogenous, foreign direct investment impacts economic growth in the short term, due to the decreasing returns on capital, but in the long term economic growth is influenced by technology growth and labor. The economy will stabilize, them for, long-term foreign direct investment has no impact on economic growth, as (De Mello, 1997) pointed out. Concerning to the deficiencies of neoclassical model which assumed exogenous technical progress, hence endogenous new growth theory assume that technology is endogenous factor and this theory is basing on some factors such as human capital, spillovers and externalities that drive growth and deliver some power for FDI to impact on the growth. Also FDI absorbed via technology transfer carries out productivity spillovers and so increase the growth (Grossman, Helpman, 1991, Loungani, Razin, 2001). (Somwaru and Makki, 2004), said if the diffusion process to rise production via the transfer of surplus and technology, FDI can promote growth.

(Borensztein and $\mathrm{Al} \mathrm{1998)}$ for developing countries carried out a special study, these outcome indicate that there is a significant positive correlation among foreign direct investments and economic, but the stock of human capital in the host country plays a crucial role. (Rana and Dowling, 1988) said that FDI and Export are both essential determinants which can explain economic performance and agree that FDI helps technology transfer and so rise capital efficiency and the growth. The empirical work of (Wei and Al, 2008) in Malaysia on the relationship among foreign direct investment and economic growth by using the Ordinary Least Square model, showed that there has a significant positive relationship among foreign direct investment and economic growth in Malaysia.(Solomon and Eka 2013) analyze the impact of FDI on Nigeria economic growth in their empirical work during 1981-2009 by using the Ordinary Least Square method, they found that FDI has a positive but insignificant impact on Nigerian economic growth for the period under study.

According to (Alejandro, 2010), FDI dramas an unbelievable role in the trade and the global economy. FDI can offer a company with many benefits such as: new markets and marketing networks, low-cost production facilities outlet to new technology goods, technology and financing for the host country or the overseas company which investment. Also FDI can offer a home of new technologies, capital processes goods, technological organization and management skills and some good externalities and spillover that can offering a solid motivation to national economic growth. (Obwona 2001) in the study of the determinants of foreign direct investment and its impact on growth in Uganda noted that macroeconomic and political stability and policy coherence is an important parameter in determining inflows of foreign investment direct investment in Uganda. Foreign direct investment contribute positively on the growth economic but not significantly. Foreign direct investment (FDI) also affects economic growth through technology transfer. In addition, (Antwi et al, 2013) also evaluate the link among foreign direct investment and economic growth. Their founding are similar to Wai and $\mathrm{Al}$ result: positive and the significance of the relationship. But they advise that national firms must use a new technology to well come foreign direct investment that protect them to drop into the monopoly market situation. In additionally study (Onu, 2012), and carried out, a plurality of FDI by using multiple regression from 1986 to 2007. He conclude a Positive but not significant effect on economic growth in Nigeria.Similar to As (Akinlo, 2004) study. 
(Olasunkanmi Owolabi-Merus , 2015) investigate the effect of foreign direct investment on Nigeria economic growth by employing annual Secondary data during 1981 to 2013 obtained from the World Bank Indicators. The econometrics methodology used in the current study is the ordinary least squares (OLS), unitary ADF root and Granger causality test. The finding of OLS illustrate that FDI positively contribute to economic growth in Nigeria, but insignificant.However, fixed gross Capital formation (GFCF) positively and statistically significant Contribution on the economic growth. Unit root tests indicated that the variables were stable or stationary and the Granger Causality test shows a unidirectionary causation running from FDI to GDP but not vice-versa.Also no relationship among GDP and GFCF.

(Chowdhury and Mavrotas, 2006) examine the effect of foreign direct investment on economic growth in Chile, Malaysia, and Thailand during the period 1969-2000.The econometrics methodology is Lagaugmented vector Auto regression. They have found Bidirectional causation running from FDDI to GDP and vice -versa. Similar in (Al-Iriani ,2007) study, done in Bahrain, Kuwait, Oman, Saudi Arabia, and United Arab Emirates during the period 1970 to 2004 to analyze the impact of FDI and Economic growth in those countries by doing Granger causality test, shows a Bidirectional causality between FDI and Economic growth.(Umoh, Jacob and Chuku, 2012) in the paper evaluate the relationship between foreign direct investment and economic growth in Nigeria during 1970-2008.Single and simultaneous equation systems has been used for the estimation equation. The result describe a positive feedback running from foreign direct investment to economic growth and from economic growth to FDI in Nigeria.

Foreign direct investment contribute positively on the growth economic but not significantly. Foreign direct investment (FDI) also affects economic growth through technology transfer. Many finding on FDI and its contribution on economic growth are mixed context. According to( Ram and Zhang ,2002) result on the impact of FDI on Economic growth in the case of cross- country shows a positive and significant impact among the both variables.in contrast, (Charkovic and Levine ,2002) found the negative impact. Further, (Dutt, 1977) result shows a significant negative effect of FDI on economic growth. In the latest study, (Umeora ,2013) in this paper used a data covering the period 1986 to 2011 by employing OLS as the estimation technique. The result indicate a negative contribution among foreign direct investment and economic growth. At last, according to the result of Olokoyo (2012) by employing data spanning between 1970 to 2007, in the end he did not amply approve with the previous researches in Nigeria.

\section{Methodology}

This section describes one methods of econometric: the regression analysis of the ordinary least squares (OLS) to evaluate the impact of the Foreign Direct Investment on economic growth proxy by Gross Domestic Product (GDP) in Niger from the year1980 to 2005 and the granger causality test to assess the causal relationship between FDI and GDP.To see if it is GDP that causes FDI or it is FDI that causes GDP. To drive this research the data come from different sources, such as, World Development Indicators, the Niger Investment Agency, and the office of national statistics (INS). In order to achieve the objectives of present study and to examine the data the statistical software Eview 8 is employing. The data analyses embrace Ordinary Least Square (OLS) regression, and Granger causality. The ordinary least squares (OLS) regression method is used because it has many advantages such as: minimizes the error sum of square, minimum variance and sufficiency, unbiaseness, consistency.

\section{Statement of Hypotheses}

H1: Foreign Direct Investment impacts significantly Niger's economic growth.

H2: It exist a Causal Relationship between Foreign Direct Investment and Economic Growth in Niger.

\section{Model Specification}

In this paper, to determine the relationship of FDI on economic growth are formulated as follows:

$\mathrm{GDP}=\beta_{0}+\beta_{1} \mathrm{FDI}+\beta_{2} \mathrm{GFCF}+\varepsilon$

Where:

$\beta 0=$ Constant $=$ Intercept value

GDP denotes the real gross domestic product growth (current US\$)

FDI denotes Foreign Direct Investment (current US\$)

GFCF denotes Gross Fixe Capital Formation (current US\$)

$\beta_{1}, \beta_{2}$ denotes the coefficients associated to the independent variables;

$\varepsilon \quad=$ Random Error term

In this study our expectations are $\beta_{0}>0, \beta_{1}>0$ and $\beta_{2}>0$, that means we are expecting a positive connection among the dependent variable and the explanatory variables. 


\section{Definition of variables}

In this paper, the dependent variable is the Gross Domestic Product, while the independent variable are represented by: Foreign Direct Investment and Gross Fixe Capital Formation. The dependent variable employ is gross domestic product (GDP). According to World Bank definition GDP is define as the changing from one year to another year and indicates the rate of the economic growth of a specific country. The Gross Domestic Product (GDP) is the greatest indicators to estimate the production of goods and services in a country over the twelve month (year).Source: The World development indicators.

The independent variables of this model are: The Foreign direct investments are the net inflows of investment to acquire a lasting management interest in an enterprise operating in an economy other than that of the investor. It is an accumulation of equity capital, reinvestment of earnings, other long-term capital, and shortterm capital as exposed in the balance of payments. FDI is the one of the important and interest variable of our study. Source: World development indicators.

Gross Fixe Capital Formation: According to the World Bank definition:" Gross capital formation (formerly gross domestic investment) consists of outlays on additions to the fixed assets of the economy plus net changes in the level of inventories". Fixed assets include land improvements (fences, ditches, drains, and so on); plant, machinery, and equipment purchases; and the construction of roads, railways, and the like, including schools, offices, hospitals, private residential dwellings, and commercial and industrial buildings. According to the 1993 SNA, net acquisitions of valuables are also considered capital formation. Gross fixe capital formation is considered as the purchases of new plant and equipment by firms, as percent of GDP. A high number is good for long-term economic growth as current investment leads to greater future production. Source: World development indicators.

\section{Analysis Of Results}

The variables listed below enclose foreign direct investment, gross domestic product, and Gross fixe capital formation, from 1980 to 2005 with 25 observations. We employ Ordinary Least Squares (OLS) estimation to evaluate the model specified in section three. In case of autocorrelation, we employ AR (1) Cochrane-Orcutt estimation to correct the model means to improve the value of Durbin-Watson (DW).

\section{Ordinary Least Square Estimation (OLS)}

Table 1. OLS result

\begin{tabular}{|l|l|l|l|l|l|l|l|}
\hline Variable & Coefficient & Std. Error & t-Statistic & Prob & R-squared & $\begin{array}{l}\text { Adjusted R- } \\
\text { squared }\end{array}$ & $\begin{array}{l}\text { Durbin- } \\
\text { Watson stat }\end{array}$ \\
\hline FDI & 8.099389 & 2.909635 & 2.783644 & 0.0106 & 0.705993 & 0.680427 & 0.6422 \\
\cline { 1 - 5 } GFCF & 1.868444 & 0.409051 & 4.567758 & 0.0001 & & & \\
\hline C & 1518.184 & 109.5424 & 13.85932 & 0.0000 & & & \\
\hline
\end{tabular}

Table 1 describes the link among GDP the dependent variable and the independent variables such as FDI and GFCF. According to the result of table 1, we observe that the R-squared and adj. R-squared are not a good fit. Also the DW= 0.6422 is not good, we suspected the presence of Autocorrelation. To solve this problem by improving the DW, the Cochrane-Orcutt iteration method: AR (1) was employed to improve the DW.

\section{Cochrane Orcutt Iterative Method}

Table 2 Cochrane Orcutt Iterative Method

\begin{tabular}{|c|c|c|c|c|c|c|c|}
\hline Variable & Coefficient & Std. Error & t-Statistic & Prob & R-squared & $\begin{array}{ll}\begin{array}{l}\text { Adjusted } \\
\text { squared }\end{array} & \text { R- } \\
\text { s. }\end{array}$ & $\begin{array}{l}\text { Durbin- } \\
\text { Watson stat }\end{array}$ \\
\hline FDI & 5.261593 & 1.385557 & 3.797456 & 0.0011 & \multirow[t]{4}{*}{0.901496} & \multirow[t]{4}{*}{0.887424} & \multirow[t]{4}{*}{1.911922} \\
\hline GFCF & 2.866092 & 0.418587 & 6.847056 & 0.0000 & & & \\
\hline $\mathrm{C}$ & 1371.806 & 133.5681 & 10.27046 & 0.0000 & & & \\
\hline $\mathrm{AR}(1)$ & 0.583954 & 0.115142 & 5.071600 & 0.0000 & & & \\
\hline
\end{tabular}

By using OLS estimation technique we get the following result: $\mathrm{GDP}=1371.806+5.261593 \mathrm{FDI}+2.866092 \mathrm{GFCF}$.

The empirical results are illustrated in the table 2. The coefficient of foreign direct investment is 5.261 in the estimate regression, it has a positive relationship with GDP, and has a t-statistic of 3.797 and a P-value of 0.0011 means $(\mathrm{t}=3.797, \mathrm{p}<.05)$ showing that a unit increase in real foreign direct investment (FDI) will increase GDP by 5.261 .

In the same way the coefficient of gross fixe capital formation is 2.866 , it has a positive relationship with GDP, and has a t-statistic of 6.847 and a P-value of 0.0000 means $(t=6.847, p<.05)$ showing that a unit increase in gross fixe capital formation will increase GDP by is 2.866 .

The Cochrane Orcutt iterative process is employed to evaluate higher-order autoregressive method. We employed this test (AR) when the value of Durbin-Watson is very low in the OLS estimation, in this study DW 
equal to 0.6422. Autocorrelation which is notice in the estimation of OLS, was deleted after the application of AR (1).The outcome of the estimation indicated that all the coefficients past $t$ test and give their expected result.

The coefficient of determination $r$-square $\left(R^{2}\right)$ of this model is 0.901 that means $9.9 \%$ variation in the model is unexplained by FDI and GFCF whereas remaining variation (90.1\%) is explained by FDI and GDP. The Durbin Watson Corrected value which is 1.911 is close to 2, indicating that there is no first-order positive or negative autocorrelation. All variables in the model past t test, means that the overall model is significant at $1 \%$, $5 \%$ and $10 \%$ of levels of significance. The $t-$ statistics shows that the relationship among FDI and GDP is statistically significant to permit the undue importance that FD I can truly replenish the investment gap that will contribute to obtain the desired rate of economic growth in Niger.

\section{Granger causality test}

Table 3 Granger Causality Results

\begin{tabular}{|lcl|}
\hline Null hypothesis & F-statistics & Probability \\
\hline GDP does not granger cause FDI & 5.44729 & 0.0135 \\
FDI does not granger cause GDP & 4.40145 & 0.0269 \\
\hline
\end{tabular}

When the probability value is less than 0.05 , we accept the null hypothesis that FDI does not granger causes GDP.The table 3 shows that the probability value of 0.0135 is less than 0.05 means that GDP granger cause FDI for this period of study while ,the F-statistics value of 5.44729 shows an average feedback effect from GDP to FDI. Also the probability value of 0.0269 is less than 0.05 means that FDI granger cause GDP for the period 1980 to 2005 while the F-statistics value of 4.40145 shows no a strong feedback effect from FDI to GDP.

\section{Conclusion}

This study has examined the impact of FDI on Niger economic growth during the period 1980 to 2005. The findings shows that foreign direct investment has a positive relationship on economic growth and statistically significant at $5 \%$ in Niger during the period of study. The granger causality test indicates that GDP granger cause FDI and FDI also granger cause GDP.There is a bidirectional causal effect between GDP and FDI but no strong. This involves that a good performance of economy is a great indicator for inflow of FDI. FDI acts as the blood of the economic growth.

To maintain this positive contribution, local government must re- invested the profits of FDI in the economy by having a good systems of governance which have some criteria as transparency and accountability. There is need to improved Agricultural Sector because it constitute the main activity in the country and to get the food sufficient features in the country and international level. To improve quality of Infrastructure, to ensure Political and economic Stability at all stages in Niger to offer assurance to investors as insecurity scares local and foreign investors.Finally local government must put in place solid policies to stimulate a positive and good environment in purpose to attract more foreign investors.

\section{References}

[1] Hansen, Henrik and John Rand, On the Casual Links between FDI and Growth in Developing Countries, University of Copenhagen, Institute of Economics, Discussion Papers, 2004, 04-30 from <http://www.econ.ku.dk/wpa/pink/2004/0430. Pdf>.

[2] Klein, Michael, Carl Aaron and Bita Hadjimichael, Foreign Direct Investment and Poverty Reduction, The World Bank, Policy Research Working Paper Series, 2001, 2613.

[3] Afşar, M. Dogrudan Yabancı Yatırımlar ve Bankacılık Sektörü. Ege Academic Review 4(1): (2004), 85-101,

[4] Caves, R.E, İnternational Corporations: The Industrial Economics of Foreign Investment, Economica. New Series 38(149), (1971), $1-27$.

[5] Macaulay, E.D , Foreign direct investment and the performance Of the Nigerian economy Proceedings of the 1st International Technology, Education and Environment Conference, 2012, Pp 629 -633.

[6] De Mello, LR and Luiz, R, FDI and Growth in Developing Countries, the Journal of Development Studies Vol.34 No.1, (1997), pp. $1-34$.

[7] Todaro, M.P, Economic development (5th Edition). New York and London: Longman., 1994

[8] Onu, A.J.C, Impact of Foreign Direct Investment on Economic Growth in Nigeria. Interdisciplinary Journal of Contemporary Research in Business, 4(5), 2012, 64-75.

[9] Denisia, V, Foreign direct investment Theories: An Overview of the main FDI theories, European Journal of Interdisciplinary Studies, 2(2), (2010), 104-110.

[10] Grossman, G, Helpman, E., Quality ladders in the theory of growth, Review of Economic Studies, Vol.58, (1991), pp.43-61.

[11] Loungani, P., Razin, A, How beneficial is foreign direct investment for developing countries? Finance and Development, Vol.38, No.2, 2001, pp. 6-9.

[12] Makki S and A Somwaru, Impact of Foreign Direct Investment and Trade on Economic Growth American, Journal of Agricultural Economics, Vol. 86, 2004, pp. 795-801.

[13] Borensztein, DC, E. et al, How Does Foreign Direct Investment Affect Economic Growth? Journal of International Economics Vol. 45, 1998, pp. 115-135.

[14] Rana, P.B, Dowling, J.M. Jr, The impact of foreign capital on growth: Evidence from Asian Developing Countries, the developing Economies, volumes 26, Issue 1, 1988, pp.3-11 
[15] Solomon, H.C and Eka, O.O, Impact of foreign direct investment on telecommunication sector on Nigerian economy, International Journal of Modern Social Sciences. 2(3), 2013, 195-215.

[16] Alejandro D, Bautista ,conference foreign direct investment Mexico, United States, Canada NAFTA, Presentation Transcript, (2010).

[17] Obwana, Morios B, Determinants of FDI and their impact on economic growth in Uganda, African Development Review 2001, Blackwell Publishers Oxford.Uk, 2001, 46-80.

[18] Antwi, S., Mills, E., Mill, G., and Zhao, X, Impact of foreign direct investment on economic growth: Empirical evidence from Ghana, International Journal of Academic Research in Accounting, Finance and Management Sciences, 3(1), 2013, 18-25.

[19] Akinlo, A.E, Foreign direct investment and Growth in Nigeria: An Empirical Investigation, Journal of policy Modelling, Vol.26, 2004, Pp627-39.

[20] Olasunkanmi Owolabi-Merus, how important is Foreign Direct Investment to Economic Growth? New Evidence from Nigeria, Pacific Business Review International, Volume 7, 2015, Issue 8.

[21] Chowdhury, A., \& Mavrotas, G, FDI and Growth: What Causes What? World Economy, 29(1), 2006, 9-19.

[22] Al-Iriani, M, Foreign direct investment and economic growth in the GCC countries: A causality investigation using heterogeneous panel analysis. Topics in Middle Eastern and North African Economies, 9(1), (2007), 1-31.

[23] Umoh, O., Jacob, A., \& Chuku, C, Foreign Direct Investment and Economic Growth in Nigeria: An Analysis of the Endogenous Effects. Current Research Journal of Economic Theory, 4(3), 2012. 53-66.

[24] Ram, R., and Zhang, K. H. Foreign direct investment and Economic growth: Evidence from Cross-country Data for the 1990s, economic Development and Cultural Change, 51(1), 2002, 205-215.

[25] Carkovic, M.and Levine, R, Does Foreign Direct Investment Accelerate Economic Growth? University of Minnesota Department of Finance Working Paper, (2002).

[26] Dutt, S, With Nehru in the Foreign Office, Minerva Associates (Publications), (1977).

[27] Umoh, O., Jacob, A., \& Chuku, C, Foreign Direct Investment and Economic Growth in Nigeria: An Analysis of the Endogenous Effects. Current Research Journal of Economic Theory, 4(3), 2012. 53-66.

[28] Ram, R., and Zhang, K. H. Foreign direct investment and Economic growth: Evidence from Cross-country Data for the 1990s, economic Development and Cultural Change, 51(1), 2002, 205-215.

[29] Dutt, S, With Nehru in the Foreign Office, Minerva Associates (Publications), (1977). 